Anna Kalinowska-Żeleźnik

Anna Lusińska

Sylwia Kuczamer-Kłopotowska

Uniwersytet Gdański

\title{
POLSKA AKCJA HUMANITARNA - LIDER SPOŁECZNY NA PORTALU SPOŁECZNOŚCIOWYM FACEBOOK
}

\author{
Abstract \\ POLISH HUMANITARIAN ORGANIZATION - THE SOCIAL LEADER \\ AT FACEBOOK
}

In the age of continued instability, constant crises, age of not coping with building-up problems of the globalizing world, increasingly the role of social leaders is taken by non-governmental organizations, such as Polska Akcja Humanitarna. It quickly and accurately diagnoses social problems, in order to reduce them. In order to meet the challenges posed in front, not only by its own region or country, but also by the globalizing world, it performs its tasks at the level of the general public. In carrying out the mission of global humanitarian aid it uses, inter alia, modern marketing communications tools, including the interactive communication in social media.

Key words: marketing communication, new media, social media, non-governmental organization

\section{Wstęp}

W XXI wieku - wieku dynamicznym, pełnym napięcia i bardzo skomplikowanym, wieku kryzysu światowego i finansowej niestabilności - coraz częściej rolę lidera społecznego w obszarach działań, w których państwo zwyczajnie sobie nie radzi lub nie ma na nie funduszy, przyjmują pozarządowe organizacje (NGO, ang. non-governmental organization $)^{1}$. Globalizacja zmieniła zasięg ich działania [Lewis

${ }^{1}$ Organizacje te na podstawie Ustawy o działalności pożytku publicznego i o wolontariacie (z 24 kwietnia 2003 r.) uzyskały w sądzie status pożytku publicznego. Należą do nich wszelkie stowarzyszenia i fundacje, a także spółki akcyjne i spółki z ograniczoną odpowiedzialnością, które nie 
2001, s. 100-101; Lewis, Kanji 2009, s. 142]. Podczas gdy w XIX-XX wieku domeną NGO-sów było głównie środowisko lokalne lub państwo narodowe, w XXI wieku coraz częściej realizują one swe zadania w skali regionalnej lub globalnej. Niezależnie jednak od zasięgu pełnią nie tylko funkcję pomagającego słabszym wolontariusza. Przede wszystkim, poprzez swą strategię i zawartą w niej misję oraz wizję, trafnie diagnozują społeczne problemy, doprowadzając do ich redukowania [Baehr 2009, s. 25-28; Singh 2014]. Dlatego też, dla niesienia ogólnoświatowego pożytku społecznego, organizacje pozarządowe, chcąc jak najlepiej realizować cele pomocowe, powinny starać się sprostać wyzwaniom, jakie stawia przed nimi nie tylko ich własny region czy kraj, ale też globalizujący się świat [Herman i in. 2010, s. 1-4]. Taka jest Polska Akcja Humanitarna (PAH), realizująca cele wspólnotowe. Cele te są realizowane na różne sposoby i z wykorzystaniem wielu dostępnych obecnie narzędzi, w tym między innymi poprzez internetową komunikację z uczestnikami otoczenia w mediach społecznościowych.

Powyższe przesłanki skłoniły autorki publikacji do podjęcia próby oceny aktywności PAH na jednym z większych i ważniejszych portali społecznościowych, a mianowicie na Facebooku. Celem głównym opracowania jest zatem ocena działań PAH prowadzonych na portalu społecznościowym Facebook. Cele szczegółowe zostały sformułowane następująco: charakterystyka specyfiki działalności PAH jako lidera społecznego; charakterystyka narzędzi internetowej komunikacji marketingowej dostępnych na portalu Facebook oraz identyfikacja działań i ocena aktywności PAH na portalu Facebook. Do realizacji powyższych celów posłużono się metodą analizy materiałów zastanych i studium przypadku.

\section{Polska Akcja Humanitarna jako lider społeczny}

Polską Akcję Humanitarną wśród innych organizacji pozarządowych można określić jako swego rodzaju lidera społecznego w zakresie ilości i jakości niesionej pomocy na skalę globalną. Jej zadaniem stało się wyzwalanie w ludziach potencjału energii i kierowanie go w określonym kierunku, na konkretne - poddane wcześniejszej weryfikacji - działania.

Termin „lider” oznacza autorytet, osobę lub organizację przewodzącą, która stoi na czele określonej grupy. Charakteryzuje go wskazywanie drogi pojedynczym ludziom lub innym organizacjom dążącym do jego naśladowania i z łatwością poddającym się jego przywództwu.

działają w celu osiągnięcia zysku (art. 20 Ustawy z dnia 24 kwietnia 2003 r. o działalności pożytku publicznego i o wolontariacie). Choć pozarządowe organizacje pomocowe istniały już w XVIII wieku (zob. de Tocqueville 2005), to obecnie jest ich dużo więcej. Działają one nie dlatego, że państwo sobie nie radzi, ale że tak jest mu wygodniej - taniej, bardziej efektywnie. Do realizacji zadań publicznych przekazuje zatem środki NGO-som. 
Lider z definicji pociąga innych za sobą, sam jednak nie może się tak nazwać. Przywódcą staje się wtedy, gdy za takiego uzna go na przykład społeczeństwo [Brémond, Couet, Davie 2007, s. 216]², a dokładniej ci, którym przewodzi, nadadzą mu tę rolę. $Z$ jednej strony jego myślenie wymaga ich wyprzedzania, $\mathrm{z}$ drugiej wpływania na nich poprzez słowa oraz czyny [Apostu 2013, s. 146-147].

Lidera cechują szczególny prestiż oraz zdolności do dobrego kontaktu z ludźmi. Jednakże bycie liderem nie jest wieczne. Robert King Merton, mówiąc o charakterystycznym cyklu jego życia, dokonał następującego rozróżnienia. Wśród liderów wskazał: tych, którzy wywierają aktualny wpływ (ludzie o ustalonej pozycji społecznej); potencjalnie wpływowych (czyli wszelkie wschodzące gwiazdy, które pną się w górę po drabinie społecznej); tych, których wpływ stopniowo zanika (ludzie, którym po osiągnięciu szczytu obniża się społeczna pozycja); osoby, których wpływ jest ukryty (jednostki takie posiadają cechy osoby wywierającej wpływ, ale nie wykorzystują tej właściwości) [Merton 2002, s. 669].

Lider musi pozytywnie wzmacniać ludzi. Niezbędna wydaje się w tym obszarze nie tylko poprawność i sprawność komunikacyjna, ale też aktualność przekazywanych treści. Jeśli chce on pociągnąć za sobą naśladowców, winien wzbudzić w nich energię oraz wiarę w sukces. Jego rola jest jednak uzależniona od tego, jak postrzegają go inni. Dlatego też przede wszystkim powinien być on wiarygodny. Będzie mógł prawidłowo spełniać swoją powinność tylko wtedy, gdy ludzie obdarzą go całkowitym zaufaniem, poznają jego wizję i zechcą ją współtworzyć. Wykonywanie ważnych i trudnych zadań zmusza go do podejmowania niełatwych decyzji. Musi być on zatem przykładem optymizmu, energii oraz entuzjazmu. Jednakże poprzez wyznaczanie dalekiego, często ambitnego celu oraz mobilizację otoczenia do podążania we wskazanym kierunku udaje mu się realizować to, czego się od niego oczekuje, a jednocześnie pozostawać w zgodzie z sobą i wyznawanymi wartościami. Ważne, by liderzy umieli analizować skutki będące rezultatem ich działalności i wyciągać z nich wnioski [Carreras, Leaverton, Sureda 2009, s. 45-48; Apostu 2013, s. 147-149].

Lider musi umieć inspirować. Działanie to obejmuje pobudzanie tego, co tkwi w ludziach. Wie on, że kryje się w nich znacznie większy potencjał niż ten, który pokazują bądź wykorzystują. Jego rolą jest pomóc im uwierzyć we własne możliwości. Jednakże podstawowa rola lidera nie polega na dawaniu gotowych rozwiązań czy odpowiedzi. Jej istotą jest motywowanie otoczenia do samodzielnego ich znajdowania.

Lider musi też umieć słuchać. Bycie dobrym słuchaczem nie polega jednak wyłącznie na słuchaniu, ale również na słyszeniu. Wiadomo dzięki temu, co wpływa na ludzką motywację, co jest ważne, co ważniejsze, a co stanowi wyłącznie pomysł. Umiejętności te pozwalają określić ludzkie bariery. Posiadając taką wiedzę, może

${ }^{2}$ Społeczeństwo to zbiorowość osób, które żyją w zorganizowanej grupie. Charakteryzuje się ono występowaniem instytucji, systemem wartości, organizacją funkcjonowania życia politycznego, gospodarczego oraz społecznego. 
się on odwoływać do mocnych stron ludzi, a także do ich zdolności czy marzeń. Może w ten sposób pomóc im przezwyciężyć trudności [Carreras, Leaverton, Sureda 2009, s. 45-48].

Liderów wyróżnia innowacyjność. Cechuje ich tendencja do zmiany dotychczasowych reguł postępowania oraz zwyczajów. Udaje się to dzięki umiejętności budowania partnerskich relacji opartych na zaufaniu, stymulujących w ludziach samodzielność i inicjatywę.

Istotne jest jednak to, że bycia liderem można się nauczyć (wzmacniając pożądane lub tłumiąc nieodpowiednie zachowania), choć nieodzownym dopełnieniem byłyby odpowiednie predyspozycje. Kto zatem może być liderem? Każdy, kogo cechuje inteligencja, żywość umysłu, głód sukcesu, inicjatywa, ambicja, dojrzałość, a także popularność oraz uczciwość, siła charakteru, pewność siebie czy zdolność akceptacji.

W systemie liberalnej demokracji społeczeństwa obywatelskiego narodziło się pojęcie lidera społecznego. To ktoś, kto działa dla dobra wspólnego, pożytku społecznego. To osoba uparta i konsekwentna w swoim działaniu, ale jednocześnie asertywna, co stanowi podstawę $\mathrm{w}$ kontaktach $\mathrm{z}$ otoczeniem zewnętrznym oraz partnerami (którzy na przykład zapragnęli realizować pewne działania niezgodnie z tym, co było ustalone wcześniej) [Otręba-Szklarczyk, Szklarczyk 2011, s. 62-63]. Otwartość pozwala jej dostrzegać inicjatywy i potrzeby osób, którym przewodzi. Potrafi ona wyznaczać wspólnotowe cele, a następnie tak zorganizować ludzki wysiłek, by dało się je zrealizować. Musi więc umieć służyć ludziom. W każdej zmianie powinna dostrzegać szanse.

Tego typu podejście reprezentuje wiele organizacji trzeciego sektora. Organizacja stanowi „duży zespół ludzi powiązanych bezosobowymi zależnościami, stworzony dla realizacji określonych celów" [Giddens 2007, s. 367]. Max Weber twierdził, że organizacje służą koordynacji ludzkich działań, a także ustabilizowanemu przepływowi w czasie i przestrzeni wytworzonych przez człowieka dóbr [Giddens 2007, s. 368]. Dostarczają one kolejnych aspektów tożsamości społecznej jednostek. Stają się sposobem ukazywania tego, kim jest dana persona. Jednocześnie kreują one tożsamość na poziomie zbiorowym, tworząc całości będące aktorami w ramach społeczeństwa. Te zbiorowe byty pomagają $\mathrm{w}$ dążeniach, ale mają swoje wymagania, swoją cenę (w znaczeniu dosłownym i przenośnym) [Babbie 2007, s. 66].

Organizacja społeczna, funkcjonująca dla pożytku publicznego, będąca społecznym liderem, często okazuje się profesjonalistą w wykonywanych przez siebie zadaniach. Pociąga za sobą zintegrowane wspólnoty, przez co jawi się jako swoisty bohater danego społeczeństwa. Zasięgiem swojej działalności może ona obejmować nie tylko obszar lokalny czy krajowy, ale także, co pokazuje przykład Polskiej Akcji Humanitarnej, zasięg globalny [Herman i in. 2010, s. 1-4]. PAH [Polska Akcja Humanitarna 2010, s. 2-5] to organizacja pozarządowa, a od 2004 roku także organizacja pożytku publicznego. Pod nazwą Polska Akcja Humanitarna działa od 1994 roku. Realizację misji czynienia świata lepszym rozpoczęła jednak już 
w 1992 roku jako polski oddział Fundacji EquiLibre za sprawą Janiny Ochojskiej. Zaczęła ona od organizacji konwojów z darami dla mieszkańców oblężonego Sarajewa. Była to pierwsza tego typu inicjatywa, dająca polskiemu społeczeństwu możliwość niesienia pomocy wszystkim cierpiącym z powodu wojny, która toczyła się tak blisko [PAH 2011].

Od tamtego czasu organizacja przeszła wiele przeobrażeń, które umożliwiły rozwój skutecznego działania. Realizując zadania pomocy, zbudowana została, a następnie ugruntowana siła PAH. Dopracowano własne, zgodne z zasadami i etyką organizacji, metody udzielania pomocy. Dlatego też „PAH jest aktywnym uczestnikiem rozwoju trzeciego sektora w kierunku jego integracji, profesjonalizacji i realizacji działań rzeczniczych w obszarze współpracy rozwojowej i pomocy humanitarnej" [Polska Akcja Humanitarna 2010, s. 3].

Misją organizacji stało się czynienie świata lepszym przez zmniejszanie cierpienia i niesienie humanitarnych wartości. Realizacja tej wizji odbywa się poprzez wielowymiarowe pomaganie ludziom w sytuacjach kryzysowych, w jak najszybszym uzyskaniu samodzielności, a także przyjęciu odpowiedzialności za własną przyszłość. Obejmuje ona również kształtowanie postaw humanitarnych i tworzenie nowoczesnej kultury pomocy w zgodzie z naczelną zasadą efektywnego działania z poszanowaniem godności człowieka.

Najważniejszym celem udzielanej przez organizację pomocy jest doprowadzenie do samodzielności jej beneficjentów [Polska Akcja Humanitarna 2010, s. 4-5] Dlatego też proces ten odbywa się we współpracy z nimi. Pozwala to na określenie przede wszystkim pomocowego zakresu i metod, a ponadto umożliwia odbiorcom samodzielne kierowanie rozwojem osiągniętych celów pomocy.

Świadczona przez organizację edukacja społeczna ma natomiast na celu budowanie odpowiedzialności za świat poprzez doprowadzenie do zmiany świadomości polskiego społeczeństwa (angażowanie do działań pomocowych oraz upowszechnianie wiedzy) w kwestiach dotyczących chociażby zależności między katastrofami humanitarnymi, sytuacją w najbiedniejszych krajach globalnego Południa, działaniami krajów bogatych prowadzącymi do pogłębiania ubóstwa, a także różnic w możliwościach korzystania z podstawowych praw człowieka.

Działania PAH mobilizowały ludzi z bardzo różnych środowisk społecznych, chcących pomagać i solidaryzować się z potrzebującymi $\mathrm{w}$ wielu miejscach na świecie. Pracując na terenach konfliktowych i pokonfliktowych, objętych katastrofami lub ubóstwem, w proces dostarczania pomocy włączano społeczności lokalne, by jak najszybciej uniezależnić je od niesionej pomocy zewnętrznej. Koncentrowano się głównie na pomocy natychmiastowej, wysyłając w te miejsca konwoje

${ }^{3}$ Są nimi wszyscy ci, którzy utracili samodzielność wskutek działań zbrojnych czy katastrof naturalnych, bądź są jej pozbawieni z powodu ubóstwa. PAH pomaga potrzebującym, uwzględniając szczególnie takie grupy społeczne, jak: kobiety, dzieci, osoby niepełnosprawne i uchodźcy, osoby wewnętrznie przesiedlone oraz repatrianci. Wyszczególnione grupy są nie tylko najbardziej poszkodowane, ale i bezbronne wobec efektów wspomnianych zbrojnych konfliktów, katastrof oraz ubóstwa. 
z darami pierwszej potrzeby - żywnością, lekami, sprzętem rehabilitacyjnym oraz środkami niezbędnymi do przeżycia [PAH 2011].

Jednakże najważniejszym celem strategicznym organizacji stała się walka z ubóstwem poprzez stworzenie możliwości korzystania z niezbywalnych praw człowieka: dostępu do wody i należytych warunków sanitarnych, edukacji, żywności, życia w godnych warunkach, zabezpieczenia życia i zdrowia w trakcie katastrof naturalnych i konfliktów zbrojnych.

Celem PAH stało się także angażowanie całego społeczeństwa do niesienia pomocy. Stąd też organizację można wspomóc poprzez wolontariat lub dofinansowanie. W ten sposób budowane jest solidarne działanie, przez które każdy, na miarę swoich środków, może pomóc innym. Dzięki temu tworzy się kulturę tolerancji oraz odpowiedzialności globalnej.

Niestety, nierówności nie da się zwalczyć bez zmiany globalnej, międzynarodowej polityki. W końcu wszyscy ludzie są tak samo odpowiedzialni za to, by słabszym z krajów rozwijających się stworzyć szansę na przeżycie. Mieszkańcom krajów rozwiniętych woda pitna, jedzenie oraz schronienie nie kojarzą się z podstawowym dobrem. Bieda jest dopiero wtedy, gdy brakuje pieniędzy na towary i usługi konsumpcyjne.

Specyfika aktywności, portfolio wykorzystywanych narzędzi oraz zakres geograficzny działań Polskiej Akcji Humanitarnej dowodzą, że jest ona klasycznym przykładem organizacji - lidera społecznego, skutecznie działającego w wymiarze globalnym. Aby zaś efektywnie realizować misję globalnej pomocy humanitarnej, PAH korzysta między innymi z nowoczesnych narzędzi komunikacji marketingowej, w tym również z interaktywnej komunikacji w mediach społecznościowych.

\section{Aktywność Polskiej Akcji Humanitarnej na portalu społecznościowym Facebook}

Zakres działań i narzędzi, jakie podmioty mają do dyspozycji, prowadząc działania z zakresu komunikacji w Internecie, stale się poszerza. Dzieje się tak między innymi ze względu na zmieniające się trendy i zachowania konsumentów. Pomimo tego faktu rozpoczęcie aktywności wymaga dokładnej analizy obszarów, w jakich podmiot pragnie komunikować się z otoczeniem, również w długoterminowej perspektywie. Wśród wielu stosowanych narzędzi komunikacji internetowej niewątpliwie istotną rolę odgrywają obecnie media społecznościowe, które z powodu dynamiki rozwoju, charakteru i zakresu funkcjonalności poszczególnych usług oraz systematycznego wzrostu liczby użytkowników stanowią ważny kanał komunikacji podmiotów z otoczeniem [Holtz, Havens 2009, s. 188-189; Guglielmo, Palsule 2014, s. 174-177]. Media społecznościowe to bardzo dynamiczne zjawisko. Jak wykazują badania, nawet na przestrzeni kilku miesięcy wygląd oraz charakter i zakres funkcjonalności poszczególnych usług może ulegać znaczącym zmianom 
[Prószyński 2012]. Dynamika zmian czy też tempo rozwoju portali społecznościowych nieprzerwanie się nasila. Aplikacje i usługi, zawierające komplementarne względem siebie możliwości, ulegają ciągłym transformacjom, by finalnie zakres ich funkcjonalności był wzajemnie bardzo zbliżony [Wagner 2014]. Tego typu przedsięwzięcia mają na celu utrzymanie lojalności obecnych użytkowników na stałym poziomie oraz uczynienie portalu bardziej konkurencyjnym celem pozyskania nowych klientów [Somers 2014].

Facebook to portal społecznościowy założony w 2004 roku przez Marka Zuckerberga, wówczas studenta Uniwersytetu Harvarda. Stworzony jako uczelniany serwis thefacebook.com, portal ten miał służyć do wymiany informacji między studentami. Obecnie to największy portal społecznościowy na świecie. Jak wynika z raportu Facebooka za pierwszy kwartał 2016 roku, serwis miał 1,65 miliarda aktywnych użytkowników ${ }^{4}$. W grudniu 2016 roku posiadał już 1,79 miliarda aktywnych użytkowników miesięcznie ${ }^{5}$, zaś w Polsce około 14 milionów (sierpień 2016) ${ }^{6}$. To oznacza, że co czwarty człowiek na Ziemi posiada na nim swoje konto. Internautów, którzy codziennie wizytują portal, jest dziś ponad 1 miliard. A przecież jeszcze w 2015 roku użytkowników odwiedzających portal codziennie było 890 milionów, zaś ponad pół miliarda korzystało z niego tylko i wyłącznie za pośrednictwem smartfonów i tabletów [Czechowicz 2015].

W wyniku usunięcia restrykcji co do możliwości rejestracji na Facebooku, portal nieustanie skupia coraz większą społeczność. Od udostępnienia serwisu wszystkim internautom (którzy ukończyli minimum 13 lat) we wrześniu 2006 roku nie odnotowano kwartału, w którym liczba użytkowników zmalałaby. Potencjał Facebooka jako kanału komunikacji marketingowej został dostrzeżony również przez sektor instytucjonalny. Tylko do końca 2007 roku ponad 100000 różnego rodzaju podmiotów rozpoczęło swoją obecność na portalu, mając do dyspozycji szereg narzędzi komunikowania się z innymi użytkownikami Facebooka.

Strony na Facebooku (fanpage) to podstawowe narzędzie komunikacji marketingowej. Stanowią one doskonałą platformę komunikacyjną dla przedsiębiorstw, organizacji i samych marek. Za pośrednictwem portalu mogą one dzielić się aktualnościami, gromadzić społeczności i aktywizować je ${ }^{7}$. Podobnie jak profil użytkownika, fanpage może być stale dostosowywany przez publikację treści, organizację wydarzeń i dodawanie aplikacji. Fan, czyli użytkownik, który lubi (tj. świadomie subskrybuje) określony fanpage, może zobaczyć nowe zdarzenia ze

${ }^{4}$ Zob. http://www.planeta.fm/Newsy/O-tym-sie-mowi/Czy-Facebook-rosnie-w-sile-czy-sie-konczy-Ilu-ma-teraz-uzytkownikow (dostęp: 28.01.2017).

${ }^{5}$ Zob. https://www.statista.com/statistics/264810/number-of-monthly-active-facebook-users-worldwide (dostęp: 28.01.2017).

6 Zob. http://www.infosocialmedia.pl/statystyki-facebooka-w-polsce-2q-2016 (dostęp: 28.01.2017).

${ }^{7}$ Subskrybenci stron firmowych (inaczej: fanpageów) w nomenklaturze portalu określani są mianem fanów. 
strony w newsfeedzie ${ }^{8}$, zaś jego znajomi zobaczą notyfikacje dotyczące aktywności wobec strony (np. polubienie postu, komentarz etc.). Polska Akcja Humanitarna jest obecna na Facebooku, to znaczy posiada na nim swój fanpage, który jest obserwowany przez blisko 84500 użytkowników portalu9

Specyfikacja głównych elementów fanpage’a przedstawia się następująco: zdjęcie profilowe (ang. avatar), zdjęcie w tle (ang. cover photo), informacje, zamieszczane zdjęcia oraz filmy, nadchodzące wydarzenia, aplikacje, opinie i recenzje, posty na stronie (tzw. oś czasu).

Zdjęcie profilowe to plik graficzny o rozmiarze minimum 180 x 180 pikseli (lub większy), skalowany do rozmiaru 120 x 120 pikseli. Ze względu na kwadratowe proporcje plik wyświetlany docelowo na profilu może zostać wykadrowany przez użytkownika. Dodanie zdjęcia profilowego do fanpage’a jest opcjonalne.

Zdjęcie w tle to plik graficzny o rozmiarze minimum 851 x 315 pikseli (lub większy, wyskalowany do wskazanego rozmiaru). Zdjęcie w tle wyświetla się na górze fanpage'a, jego dodanie jest opcjonalne. Zgodnie ze zmianą $\mathrm{w}$ regulaminie portalu, cover photo może zawierać hasła promocyjne lub prosprzedażowe, zaś tekst na grafice może zajmować ponad $20 \%$ jej powierzchni.

Kolejny element fanpage’a organizacji to informacje umieszczane na profilu, które mogą dotyczyć samej organizacji, podejmowanych przedsięwzięć, aktualności oraz wszystkich innych zagadnień ważnych dla właściciela profilu.

Podobnie jak w przypadku prywatnych profili użytkowników Facebooka, fanpage'e organizacji mogą zawierać materiały filmowe lub zdjęciowe. Zakładki „Zdjęcia” i „Filmy” przedstawiają materiały multimedialne opublikowane na fanpage’u w sposób chronologiczny.

Na profilu organizacji na Facebooku znajdują się również zapowiedzi nadchodzących wydarzeń. Box „Nadchodzące wydarzenia” jest zlokalizowany w lewej części fanpage’a i przedstawia listę stron wydarzeń (eventów) administrowanych lub współadministrowanych z poziomu fanpage’a organizacji.

Aplikacje to box zawarty w lewej części fanpage’a. Przedstawia on listę maksymalnie trzech aplikacji podłączonych do fanpage’a organizacji na Facebooku. Istota wykorzystania aplikacji w komunikacji marketingowej została szerzej przedstawiona w dalszej części niniejszego artykułu.

Dział recenzji to miejsce, w którym zestawiane są opinie i recenzje użytkowników na temat poszczególnych przedsiębiorstw, organizacji, marek, produktów, wydarzeń, spotkań, akcji itp. Box z recenzjami znajduje się w lewej części fanpage’a.

Posty na stronie to główny element fanpagea. Jest to wertykalny zbiór publikacji dodanych przez administratorów strony. Przedstawia aktualne i wyróżnione

${ }^{8}$ Newsfeed (aktualności) - prezentowany w sposób wertykalny strumień postów, tj. publikacji i zdarzeń od osób i fanpageów, które użytkownik obserwuje na Facebooku. Zdarzenia prezentowane w newsfeedzie to między innymi zmiany statusu, zdjęcia, filmy, linki, aktywność w aplikacjach oraz polubienia.

${ }_{9}$ Dane z fanpage’a PAH z dnia 28.01.2017 r. 
posty z przeszłości w sposób chronologiczny. Podobnie jak w przypadku publikacji umieszczanych przez użytkowników, inni użytkownicy Facebooka mogą polubić, skomentować i udostępnić posty z fanpage’a organizacji kolejnym użytkownikom.

Dodatkowe elementy, jakie może zawierać i zawiera struktura fanpage’a, to na przykład zakładka „Notatki” z najważniejszymi skrótowymi informacjami, zakładka „Polubione przez tę stronę” oraz „Inni to lubią”. Fanpage Polskiej Akcji Humanitarnej zawiera w swojej strukturze wszystkie powyższe dodatkowe elementy.

Badania mediów społecznościowych pokazują, że pomimo ogromnej różnorodności specyfiki działalności podmiotów obecnych na Facebooku można dokonać swoistej ujednoliconej klasyfikacji tzw. dobrych praktyk działań marketingowych podmiotów na portalu [Holtz, Havens 2009, s. 188-189; Kaznowski, 2008, s. 121-156; Drell 2012]. Należy do nich między innymi:

- Opracowywanie treści i grafiki na fanpage’u w sposób zgodny z aktualnymi trendami w projektowaniu graficznym oraz przede wszystkim w sposób zgodny z identyfikacją wizualną marki. Wpływa to niewątpliwie na kreowanie pozytywnego wizerunku marki oraz na budowanie zaangażowania społeczności fanpage’a i wzrost zasięgu organicznego ${ }^{10}$.

- Optymalizowanie częstotliwości publikacji, typu publikowanych treści i ich zakresu tematycznego oraz optymalizowanie udziału materiałów multimedialnych w stosunku do tekstów. Działania te zapewniają wzrost zaangażowania lub zapobieganie spadkom zaangażowania społeczności dzięki konsekwentnie utrzymywanej komunikacji, zapewniają wzrost organiczny [SimplyZesty 2012] oraz zapobiegają sytuacjom zagrażającym wizerunkowi marki.

- Monitoring aktywności i bieżąca obsługa użytkowników na fanpage’u obejmująca między innymi: aktywny dialog ze społecznością (odpowiedzi na komentarze), odpowiedzi na pytania fanów zawarte w komentarzach oraz w wiadomościach prywatnych, obsługe postów, opinii i recenzji dodanych na fanpage'u przez użytkowników w celu na przykład zapobiegania sytuacjom kryzysowym. Poprzez nawiązanie i utrzymanie dialogu ze społecznością działania te wpływają pozytywnie na wizerunek marki, zwiększają liczbę fanów oraz dają możliwość szybkiej reakcji na wpisy i komentarze o potencjale kryzysowym.

- Niestandardowe działania dodatkowe, typu: konkursy organizowane za pośrednictwem dedykowanej aplikacji lub pod publikacją na fanpage'u, kwizy, loterie i inne aplikacje. Działania takie wspierają i urozmaicają komunikację marki, dając tym samym szansę na wzrost zasięgu organicznego, wzrost liczby fanów oraz utrzymanie ich wysokiej aktywności na profilu.

${ }^{10}$ Wzrost organiczny na portalu Facebook to wartość wyrażająca liczbę unikatowych użytkowników, którzy mieli styczność $\mathrm{z}$ daną publikacją (zobaczyli post i ewentualnie podjęli wobec niego określoną aktywność). 
Fanpage Polskiej Akcji Humanitarnej wydaje się prowadzony w zgodzie z wymienionymi wyżej dobrymi regułami marketingowymi prowadzenia profilu na Facebooku. Treść oraz grafiki fanpage’a odzwierciedlają aktualne trendy w projektowaniu graficznym, są spójne i zgodne z identyfikacją wizualną marki. Te elementy stale wpływają na wzmocnienie prestiżu tej organizacji jako lidera społecznego.

Typ publikowanych treści i ich zakres tematyczny są dokładnym odzwierciedleniem specyfiki działalności PAH, a sposób redagowania tekstów i wybór materiałów multimedialnych zapewniają wysoki poziom zaangażowania społeczności profilu oraz pozytywny odbiór organizacji wśród internautów. W ten sposób organizacja ta, jak na lidera przystało, buduje swoją wiarygodność i bardzo pozytywnie oddziałuje na ludzi. Potwierdzają to między innymi recenzje internautów, na przykład Piotr Ems 26 listopada 2016 roku zrecenzował PAH, przyznając organizacji pięć gwiazdek oraz pisząc: „Bardzo was podziwiam i darzę wielkim zaufaniem. Dzięki wam ludzie, którym pomagacie bezpośrednio, odzyskują godność i mają zawsze trochę ciężaru mniej w życiu. A z nas, którzy Was wspierają, zdejmujecie uprzedzenia i wyciągacie na wierzch poczucie solidarności i odpowiedzialności. Dzięki, że jesteście!!!”" Należy podkreślić, że internauci w 917 z 1200 zamieszczonych opinii przyznali PAH pięć gwiazdek ${ }^{12}$.

Na fanpage’u Polskiej Akcji Humanitarnej można również zaobserwować działania z zakresu monitoringu aktywności poprzez bieżącą obsługę użytkowników w postaci dialogu prowadzonego ze społecznością, obsługi postów, opinii i recenzji, reakcji na wpisy oraz komentarze użytkowników. Oprócz wymienionych, standardowych działań monitoringowych, PAH efektywnie przypomina o wszelkich możliwościach udzielenia wsparcia swojej aktywności. W poście z 28 stycznia czytamy: „Podacie dalej? Przekaż swój 1\% na rzecz PAH (KRS 0000136833)! «Ryczałtowcy» mogą rozliczać się tylko do końca stycznia. Zapraszamy do korzystania z bezpłatnego programu: http://www.pah.org.pl/jedenprocent. Dzięki waszemu wsparciu w 2016 roku PAH prowadziła projekty wodno-sanitarne (budowa i naprawa ujęć wodnych, sieci wodno-sanitarnych, toalet), żywnościowe (dystrybucja paczek z żywnością, wspieranie lokalnych piekarni, prowadzenie stołówek), zapewniała produkty pierwszej potrzeby (naczynia, koce, materace, środki higieniczne), pomoc medyczną. Twoje wsparcie przekłada się na realną pomoc. Dziękujemy!"13.

Dobre praktyki widać także w niestandardowych działaniach dodatkowych na profilu pod postacią choćby aplikacji dla użytkowników „ZaPLONuj zmiany z PAH”, umożliwiającej zapoznanie się z metodą PLONowania zmian w swojej kuchni. Innym przejawem nieszablonowych metod komunikowania marketingowego ze społecznością może być wcześniej wspomniana aplikacja QUIZ, sprawdzająca wiedzę

${ }_{11}$ Zob. https://www.facebook.com/pg/PolskaAkcjaHumanitarna/reviews/?ref=page_internal (dostęp: 28.01.2017).

12 Tamże.

${ }_{13}$ Zob.https://www.facebook.com/pg/PolskaAkcjaHumanitarna/posts/?ref=page_internal (dostęp: 28.01.2017). 
o zawodzie pracownika humanitarnego. Ponadto organizowane są wydarzenia, które na różne sposoby komunikują o realizowanych przez PAH celach. Przykładem może być impreza sportowa „\#iegamDobrze dla \#Aleppo”14, która odbyła się w Warszawie, zbiórka funduszy na rzecz ofiar wojny w Syrii zorganizowana podczas spotkania noworocznego Naczelnej Rady Adwokackiej w Warszawie ${ }^{15}$, czy toruński koncert muzyczny 27. Afryka Reggae Festiwal ${ }^{16}$.

Powyższe przykłady wskazują na kolejną cechę dobrego lidera, jaką charakteryzuje się PAH, a mianowicie umiejętność inspirowania ludzi do podejmowania działań. Poprzez różne akcje organizacja ta skutecznie motywuje otoczenie do znajdowania samodzielnych rozwiązań istniejących problemów.

Reasumując dokonaną analizę obecności i aktywności Polskiej Akcji Humanitarnej na portalu społecznościowym Facebook, można stwierdzić, iż organizacja ta w sposób prawidłowy wykorzystuje narzędzie komunikacji podmiotów w mediach społecznościowych, jakim jest fanpage. W ocenie autorek niniejszego opracowania fanpage PAH posiada wiele atrybutów efektywnego narzędzia komunikacji w mediach społecznościowych. O jego skuteczności mogą świadczyć choćby sukcesy prowadzonych na profilu akcji pomocowych, w tym na przykład założonego na Facebooku w 2013 roku wydarzenia pod tytułem „Przekazuję swoje punkty PAYBACK na Pajacyka” (dzięki fanom na Facebooku organizacji udało się zebrać 100000 złotych na dożywianie dzieci).

\section{Zakończenie}

Polska Akcja Humanitarna korzysta między innymi z nowoczesnych narzędzi komunikacji marketingowej, w tym również $\mathrm{z}$ interaktywnej komunikacji w mediach społecznościowych. Głównym narzędziem wykorzystywanym w tym procesie jest jej fanpage na Facebooku, zawierający aktualne treści informacyjne oraz grafiki będące odpowiedzią na zaangażowanie licznej społeczności profilu.

Fanpage PAH umożliwia organizacji skuteczny dialog z otoczeniem, pozwala efektywnie monitorować jej aktywność oraz zapewnia odwiedzającym profil właściwą mieszankę informacji i rozrywki. Jest prowadzony w sposób zgodny z dobrymi praktykami komunikacji marketingowej w mediach społecznościowych, co finalnie przekłada się na skupienie wokół organizacji licznej, zaangażowanej społeczności, na dobry wizerunek Polskiej Akcji Humanitarnej oraz na podniesienie poziomu rzeczywistych możliwości realizowania misji organizacji społecznej i pomocy potrzebującym na świecie.

\footnotetext{
14 Tamże.

15 Tamże.

16 Tamże.
} 


\section{Bibliografia}

Apostu D.-C. (2013), Non-Governmental Organization Leadership and Development. A Review of the Literature, „Manager”, nr 17, https://www.questia.com/library/journal/ 1P3-3282975301/non-governmental-organization-leadership-and-development (dostęp: 6.02.2017).

Babbie E. (2007), Istota socjologii. Krytyczne eseje o krytycznej nauce, tłum. M.A. Miernik, Wydawnictwo Naukowe PWN, Warszawa.

Baehr P.R. (2009), Non-Governmental Human Rights Organizations in International Relations, Palgrave Macmillan, New York.

Brémond A., Couet J.-F., Davie A. (2007), Kompendium wiedzy o socjologii, tłum. K. Malaga, Wydawnictwo Naukowe PWN, Warszawa.

Carreras I., Leaverton A., Sureda M. (2009), Leaders for Social Change: Characteristics and Competencies of Leadership in NGOs, Institute for Social Innovation, ESADE.

Czechowicz B. (2015), Facebook ma już ponad 1,4 miliarda aktywnych użytkowników, PCLab.pl, 1.02.2015, http://pclab.pl/news61762.html (dostęp: 8.09.2015).

Drell L. (2012), Facebook Timeline: 9 Best Practices for Brands, Mashable, 17.05.2012, http:// mashable.com/2012/05/17/facebook-timeline-brand-tips/ (dostęp: 11.09.2015).

Giddens A. (2007), Socjologia, tłum. A. Szulżycka, Wydawnictwo Naukowe PWN, Warszawa.

Guglielmo F., Palsule S. (2014), The Social Leader: Redefining Leadership for the Complex Social Age, Bibliomotion, Brookline.

Herman M.G., Lecy J.D., Mitchell G.E., Pagé C., Raggo P., Schmitz H.P., Viñuela L. (2010), Transnational NGOs: A Cross-Sectoral Analysis of Leadership Perspectives, SSRN Electronic Journal, https://www.researchgate.net/publication/247778046_Transnational_NGOs_A_ Cross-Sectoral_Analysis_of_Leadership_Perspectives (dostęp: 5.02.2017).

Holtz S., Havens J.C. (2009), Tactical Transparency. How Leaders Can Leverage Social Media to Maximize Value and Build Their Brand, Jossey-Bass, San Francisco.

https://www.facebook.com/pg/PolskaAkcjaHumanitarna/posts/?ref=page_internal (dostęp: 28.01.2017).

https://www.facebook.com/pg/PolskaAkcjaHumanitarna/reviews/?ref=page_internal (dostęp: 28.01.2017).

https://www.statista.com/statistics/264810/number-of-monthly-active-facebook-users-worldwide (dostęp: 28.01.2017).

http://www.infosocialmedia.pl/statystyki-facebooka-w-polsce-2q-2016 (dostęp: 28.01.2017).

http://www.planeta.fm/Newsy/O-tym-sie-mowi/Czy-Facebook-rosnie-w-sile-czy-sie-konczy-Ilu-ma-teraz-uzytkownikow (dostęp: 28.01.2017).

Kaznowski D. (2008), Nowy marketing, VFP Communications, Warszawa.

Lewis D. (2001), The Management of Non-Governmental Development Organizations: An Introduction, Routledge, New York.

Lewis D., Kanji N. (2009), Non-Governmental Organizations and Development, Routledge, New York.

Merton R.K. (2002), Teoria socjologiczna i struktura społeczna, tłum. E. Morawska i J. Wertenstein-Żuławski, Wydawnictwo Naukowe PWN, Warszawa.

Otręba-Szklarczyk A., Szklarczyk D. (2011), Między światami: współpraca nauk społecznych z gospodarka w Polsce, [w:] S. Rudnicki (red.), Nowe perspektywy. Nauki społeczne dla gospodarki, Wydawnictwo Wyższej Szkoły Europejskiej im. ks. Józefa Tischnera, Kraków.

PAH (2011), Historia, http://www.pah.org.pl/o-pah/96/historia (dostęp: 8.09.2015).

Polska Akcja Humanitarna (2010), Strategia działania PAH 2010-2014, Warszawa. 
Prószyński J. (2012), Pijaru Ficzery \#19, Pijaru Koksu Blog z 2012 roku, http://pijarukoksu.pl/ pijaru-ficzery-19.html (dostęp: 8.09.2015).

SimplyZesty (2012), Facebook Brand Posts Only Reach 16\% of Your Fans [Infographic], http:// www.simplyzesty.com/Blog/Article/April-2012/Facebook-Brand-Posts-Only-Reach16-Of-Your-Fans-Infographic (dostęp: 11.09.2015).

Singh K. (2014), Servant Leadership in Non-Governmental Organizations (NGOs), „Journal of Administrative Science", vol. 11, iss. 1.

Somers R. (2014), Instagram Video vs. Vine: Which Is the Video Marketing Champ?, „MarketingProfs", http://marketingprofs.com/opinions/2013/24073/instagram-video-vs-vinewhich-is-the-video-marketing-champ (dostęp: 8.09.2015).

Tocqueville A. de (2005), O demokracji w Ameryce, tłum. B. Janicka i M. Król, Fundacja Aletheia, Warszawa.

Wagner K. (2014), Messaging Wars: Vine vs. Instagram, Facebook, Twitter, Snapchat, Mashable, 4.04.2014, http://mashable.com/2014/04/04/social-network-messaging-vine (dostęp: 8.09.2015). 